\title{
How GCC University Students Get Local News and Information
}

\author{
Mokhtar Elareshi ${ }^{1}$, Abdul-Karim Ziani ${ }^{2}$, Barrie Gunter ${ }^{3}$ \\ ${ }^{1}$ University of Tripoli, Libya \\ ${ }^{2}$ University of Bahrain, Bahrain \\ ${ }^{3}$ University of Leicester, United Kingdom \\ Correspondence: Mokhtar Elareshi, University of Tripoli Libya
}

Received: June 19, 2014

Accepted: June 30, 201

Available online: August 28, 2014

doi:10.11114/smc.v2i2.443

URL: http://dx.doi.org/10.11114/smc.v2i2.443

\begin{abstract}
This paper reports a study of the use of local news sources by young people in GCC countries. With the expansion of pan-Arab news services, especially via satellite TV channels, concern has grown that these well-resourced news operations have pulled audiences away from local news suppliers. New research reported here indicates that there is still an appetite for local news and that even young people - who have displayed the greatest enthusiasm for the newer services - will tune into local news services both online and offline. Local services may represent niche markets and cater to specific news interests that have prevailed despite the popularity of pan-Arab news services. 1221 media and communication students completed a survey, reporting how and where they get their news in different GCC regions. The research found that most respondents followed what was happening in their local communities and that their news consumption could be quite varied. Rather than relying on one or two main sources of local news, most respondents reportedly used a wide variety of online and non-online sources depending on which local topic they were seeking information about.
\end{abstract}

Keywords: local news, young Arabs, social media, GCC countries, news consumption.

\section{Introduction}

Media such as newspapers and television have represented important aspects of many people's lives in the Arab world for many years (Boyd, 1999). These media have been valued and used in particular as sources of news. Keeping up with the news is also important to people in this region (Abdel Rahman, 1998; Marghalani, Palmgreen, \& Boyd, 1998). Since the mid-1990s, the media landscape in the Arab world has changed dramatically (Boyd \& Shatzer, 1993; Ghareeb, 2000). Such change has been most clearly manifested in the emergence of satellite broadcast television and the Internet. These platforms have facilitated a shift from mostly localized news production and distribution to pan-Arab world news services (Ayish, 2001; Miladi, 2006). People in the region have embraced these international news services because they offer different perspectives on news issues from those provided by their largely government-controlled local news services (Al-Shaqsi, 2000; Marghalani et al., 1998). Pan-Arab news services also support the concept of an Arab perspective on news issues to rival the Western perspective, which previously dominated the international news services that could be received in the Middle East (Miladi, 2006). The ascendancy of pan-Arab news services via satellite television has also triggered tensions in specific Arab countries, particularly within their governments, because they have had to relinquish some of the control they previously enjoyed over daily news agendas (Elareshi \& Gunter, 2010). The new services have also raised questions about what the future holds for the continuing local news services that lack the resources of the news pan-Arab operations and present news packages that are often less appealing (Elareshi \& Gunter, 2010).

Satellite television news in the Arab world has demonstrated an ability to reach people quickly and effectively with current and relevant news packages just as much as it has been shown to do in other parts of the world (Gant \& Dimmick, 2000; Huang, 2009). Moreover, the principal media companies behind satellite news broadcasts in the region (e.g., Al Jazeera and Al Arabiya TV) have also taken advantage of the Internet to reach as wide a market as possible. These services have proved to be especially popular with young adults, and have pulled them away from local news outlets (see e.g., Elareshi \& Gunter, 2010). In this context, it is worth asking whether there is still an appetite for local news in the Arab world and whether this is true in particular for young adults in the audience. Research is reported in 
this paper that explored this issue with university students in GCC countries.

The main aim of this study was to take a descriptive approach to the analysis of how GCC university students get local news and information about their communities using online/offline services. It also examined reported use of new technologies both in a broad sense and in relation to local news consumption. In so doing, it aimed to answer questions about emergent patterns of use of news sources in these countries have arisen following the rapid growth of internet access in the Arab world (Dennis, Martin, \& Wood, 2013; Ghannam, 2012; Ghonim, 2012).

\section{Local News Consumption and Online Media}

Since the Arab uprisings of late 2010, Arab audiences have increasingly turned to a wide range of news providers to get their local and non-local news. Evidence has emerged that Arab GCC news consumers, for example, devote increasing amounts of time to watching TV shows online at the expense of using other media platforms (Dennis et al., 2013; 2014). In this context, local news and current events have become much easier to access on multiple platforms, especially since the spread of the Internet, which enables users to find out local news and information effortlessly (Ghonim, 2012; Huang, 2009; The Arab Social Media Report, 2014). The Internet is an environment in which people can gain access to different content and engage in interpersonal transactions. The use of this environment to obtain local news is one part of this activity. The use of social media sites is also a subcomponent of online behavior and has multiple purposes including gaining access to local news (Pempek, Yermolayeva, \& Calvert, 2009). The Internet has become an increasingly prominent source of local news information as more mainstream news services have migrated to it and more people have gained access to it (Yuan \& Kosicki, 2003).

Despite the spread of the Internet, satellite TV services are the most popular news media in the Arab world as they provide important talking points (Elareshi \& Gunter, 2010; Huang, 2009; Karam, 2007). Dennis et al. (2013) found that most Arab viewers spend around three hours daily watching TV, while the Internet is the second most popular news medium. It is apparent that if television is to capture and cultivate young people as news consumers, it must cater to their tastes and priorities both in terms of the types of news being presented and also in the way that news is presented. However, several studies (see e.g., Dutta-Bergman, 2004; Huang, 2009; Pew Research Center for the People and the Press, 2002; Zerba, 2004) have indicated that print, television and radio have lost many of their consumers in other parts of the world because of the shift towards online news. This raises questions about whether news consumption patterns in the GCC countries have also been shifting in the same way as a result of the emergence of new news services in media sectors. For example, young adults were found to be less inclined to rely on the morning papers for their up-to-date news. Instead, they are interested in news on demand, when it works for them. They want control over their media, rather than seeing them controlled by people such as (Murdoch (2005) as cited in Huang, 2009). In this context, however, limited research is available specifically about the use of new technology for local news communities by GCC university students (Dennis et al., 2013).

In the Arab world, news supply has traditionally been closely controlled by governments and as such many Arab countries have been served by narrow and restricted news agendas (Anas, 2013; Ayish, 2001; Elareshi \& Gunter, 2010). This position has changed during the digital era in two ways. First, the Arab world has witnessed the emergence of pan-Arab satellite TV news services, led by Al Jazeera in the mid-1990s; second, the region has adopted the Internet, which has provided a further platform for news services over which Arab governments have less control.

In countries in which the main news media are tightly controlled by the government, there is an additional incentive for people to go online for their local news if they believe they can access more uncensored information in that setting (Pempek et al., 2009). At that time, news consumption was dominated by local newspapers, TV and radio stations, and government websites controlled by the state (Anas, 2013; Ayyad, 2011; Howard et al., 2011). These news platforms reflected a motivation to promote only domestic policy, to maintain stability and to promote national identity. They operated as extensions of central state control over citizens (Anas, 2013; Elareshi \& Al-Jaber, 2014; Rugh, 2004). These characteristic features of traditional media are being challenged by the online content, which has changed the media habits of audiences, especially those of young adults (Miliany, 2013). This rapidly evolving news landscape raises questions about how media consumers in GCC regions - particularly young adults - make decisions about which source to turn to for their local news. Evidence has emerged (see e.g., Dutta-Bergman, 2004; Elareshi \& Gunter, 2012) of competition between new and old media when both cater to the same audience needs and gratifications (see e.g., Heikkinen \& Reese, 1986; Levy \& Windahl, 1984). This pattern has migrated to the Arab world, with its burgeoning suite of news providers, and the newer news media have begun to usurp the older ones (Dennis et al., 2013). The research reported here aimed to discover how young GCC media users access media content and whether there is any evidence that they still retain an appetite for traditional, local news services in the face of fierce competition for their attention from the newer ones. 


\subsection{Online Media and Young Arab Adults}

The Internet has proved to be especially popular with young people (Pew Research Center for the People and the Press, 2002). This is as true of the Arab world as it is elsewhere. Young Arabs spend up to four hours daily on online pursuits, with social media sites rapidly growing in popularity (Elareshi \& Al-Jaber, 2014; Miliany, 2013). The Internet has captured the interest of young Arabs as a source of local news as well as entertainment (Aday, Farrell, Lynch, Sides, \& Freelon, 2012; Dennis et al., 2013, 2014; Simsim, 2011), with most young men using the Internet. The Internet encourages young people to keep up with news and information.

According to recent studies, especially during the so-called 'Arab Spring', Arab youth dominated the demographic profile of the online population (Ajami, 2012; Dennis et al., 2013, 2014; Ghonim, 2012; Miliany, 2013; Ryan, 2011). Dennis et al. (2014) indicated that the majority of young GCC citizens are heavily reliant on the Internet for news and entertainment. Young adults, in general, were found to consume news primarily to monitor the world around them, identify their personal values for truth, and to gain basic knowledge to refer to in conversations (Huang, 2009). Furthermore, social media sites emerging in Arab societies have had important consequences for young people's lives, especially in relation to their local news, political attitudes and activities (Dennis et al., 2014; Miliany, 2013; Simsim, 2011). Elareshi and Al-Jaber (2014) examined the growing influence of social networks as alternative news media in the GCC region and concluded that the Internet was seen as a reliable and important source of information. Most respondents agreed that news and information accessed via the Internet were credible and independent, and they felt that they have improved. Similar results were found by Elamanza et al. (2013).

Furthermore, the use of online services by local citizens has affected the relationships between them and their governments (Ghonim, 2012; Miladi, 2011). Online services are advantageous because they allow their users to express their views 'openly' (Ellison, Steinfield, \& Lampe, 2007) and to exercise choice on what news to access and how to access it (Huang, 2009). Several studies have examined how and why people go online (Correa, Hinsley, \& de Zuniga, 2010; Ghonim, 2012; Lin \& Lu, 2011). Dennis et al. (2014) found that more than a third of internet users in the Middle East and GCC region go online to watch TV, and they are twice as likely to stream shows online as to download them to a device. This may be the point in the Arab world at which users have begun to take more control of their TV viewing habits, as they are now able to watch TV shows at their own convenience most of the time (Dennis et al., 2014). People in the GCC region - especially young viewers - are even able to interact online with the TV shows, newspapers and radio they consume, and they can discuss media content online too. For example, GCC internet users watch more TV programming content from their own countries than other content (Ghannam, 2012; Miliany, 2013; Simsim, 2011).

A few studies have begun to investigate the relationship between Arab youth and Internet use, which poses several questions regarding the social dimension of technology and its impact, patterns of uses, and objectives (Ayyad, 2011; Miliany, 2013). Internet users use the Internet to communicate with one another, to build relationships and friendships, to acquire information and entertainment, to do their shopping, and to enhance their knowledge and skills. These activities express the variety of uses and the contrasting purposes of the users.

Many Arab university students have increasingly taken advantage of online sources to complete course assignments (Metzger, Flanagin, \& Zwarun, 2003), but they also go further by seeking entertainment and local news about their local communities (Dennis et al., 2014; Ghonim, 2012). In many cases, they attempt to express their political views while online (Ayyad, 2011; Colombo, 2012; Eva, 2012). Sources available online can provide students with quick access to government documents, scholarly works, and databases located at geographically remote institutions, which makes the Internet a valuable information source for students (Metzger et al., 2003; Schwarz, 1994). As a consequence, students have grown accustomed to going online to obtain information for educational purposes. In many ways, the last ten years has brought a level of energy to the news format in the Arab world not seen for a long time.

The current research addressed a number of questions concerning the use and importance of local news to young and well-educated news consumers in the Middle East. The key questions examined here were as follows:

RQ1: Are young Arab news consumers interested in local news issues?

RQ2: How much local news do they usually consume?

RQ3: Are there any preferred news sources they choose to consume for local news?

RQ4: Are there particular news issues on the local front in which they are especially interested?

RQ5: Do news consumption patterns and preferences differ between genders and across regions?

RQ6: Do young Arab news consumers engage interactively with the news online?

\section{Method}




\subsection{Sample}

A self-completion questionnaire survey was carried out in January 2014 with a random sample of 1221 students from universities in Bahrain, Kuwait, Saudi Arabia, UAE and Oman, utilising media lecturers at these universities. The sample comprised 331 respondents from Bahrain University, 141 from Kuwait University, 274 from the Universities of Jazan and Dammam (Saudi Arabia), 190 from Ajman University (UAE), and 285 from Muscat University (Oman). This survey mainly targeted media and communication departments in these universities to collect the data. In each department, a random sample was selected from different year levels. Students from each year level were asked to fill in the survey voluntarily.

\subsection{Questionnaire}

A pre-structured questionnaire included questions about local news consumption habits, general news interests, local news issues, opinions about place of residence, online activities, mobile phone and computer use, and personal details. Questions were obtained with permission from the Pew Research Center and some re-wording was deployed, where relevant, to reflect local media market circumstances.

The local news consumption questions asked respondents about the frequency with which they kept up with news in general, how they described themselves with regard to their usual local, national and international news consumption, whether they have access to local news sources (offline/online) that provide them with the news they seek, whether they have favorite sources for local news, how well these services performed in providing news information, and whether it is easier/harder for them to find news today compared to five years ago. Additional questions enquired into their consumption of local newspapers. Respondents were asked about the impact of local newspapers on their reading future and whether they are willing to pay to receive their newspapers.

A second set of questions asked respondents about the frequency with which they consume local news and information from different sources. They were asked to state the extent to which they follow specific local news sources (offline/online). These included the local newspapers, the local websites of newspapers, local TV news broadcasts, local websites for TV news, local radio, local websites of radio stations, persons or organizations they follow on social networking sites, and internet searches using a search engine such as Google. The questions were measured on a six-point scale from 'daily' (1) to 'don't know' (6).

Respondents were required to state which local issues were of most interest to them. These included information about local restaurants, cafés or stores, community or neighborhood events, local crime, local schools and education, local politics, campaigns and elections, local government activity, local breaking news, local job openings, and local social services that provide assistance with matters such as housing, food, healthcare and child care.

With regard to internet services, respondents were asked to state whether they have ever engaged in any of the following activities online: Contributing to an online discussion or message board about their local community; customizing their homepage to include their favorite local information or news sources or issues; emailing a link to a local news story or local news video to someone they know; contributing their own article, opinion piece, picture or video about their local community to an online news site; commenting on a local news story or local blog they read online; and posting news or information about their local community on a social networking site such as Facebook or Twitter. These activities were measured on a three-point scale: 'yes', 'no', and 'don't know'.

Respondents were next invited to evaluate their place of living, their local influence, and details about their gender, age, and family monthly income. In all, $58.1 \%$ of the final sample was female and $41.9 \%$ was male. $80.5 \%$ of the sample lived in families earning more than $\$ 1001$ a month, $17.4 \%$ lived in middle-income families earning from $\$ 501$ to $\$ 1000$ a month, while only $2 \%$ lived in families earning less than $\$ 500$ a month. With regard to the descriptions of place of residence, $70 \%$ of respondents described their community as a large city, while around $16.7 \%$ said they lived in a small city or town, or a suburb near a large city $(11.5 \%)$. Only $2.2 \%$ said they lived in a rural area.

\section{Results}

Basic descriptive results for news consumption habits, news interests and news-related opinions are presented below and supplemented by statistical tests designed to reveal significant differences in news consumption and interest profiles of respondents from different GGC nations and between specific demographic groups.

\subsection{General News Interest}

Local news information can now be received via a number of different platforms in the Arab world. Within the past decade, television and the Internet have been the news sources most frequently used by young people in both the Western and Arab worlds (Al-Jaber \& Gunter, 2013; Barakat, 2011; Gunter, 2010; The Arabic network for Human Rights, 2004). 
In this survey (RQ1), around half of all respondents (52\%) said they enjoyed keeping up with the news in general; $31 \%$ said 'some', $16 \%$ 'not much', and only $1.3 \%$ 'don't follow'. Male respondents $(84 \%)$ were more likely than females $(29 \%)$ to say that they enjoyed keeping up with the news 'a lot'. While $43 \%$ of female respondents said they had 'some' interest, only $14.5 \%$ of males said as much $\left(\mathrm{X}^{2}=666.40, \mathrm{df}=4, \mathrm{p}<0.000\right)$.

By country, around three fifths of Bahraini (63.7\%) and KSA (61.3\%) respondents said they enjoyed keeping up with the news 'a lot', compared with $47 \%$ of Omani, $46 \%$ of UAE and only $25 \%$ of Kuwaiti respondents. Less than a quarter (23\% Oman, 18\% Kuwait, 17\% UAE, 14\% KSA, 10\% Bahrain) said they did not much enjoy doing so $\left(\mathrm{X}^{2}=114.04\right.$, $\mathrm{df}=12, \mathrm{p}<0.000)$. Other studies in the Arab world have confirmed that young adults are keen on keeping up with news and information (Elareshi \& Gunter, 2010; Ghannam, 2012).

\section{Local, National and International News}

Respondents across nations had similarly broad views on local news. Around three fifths $(60.1 \%)$ of all respondents indicated that they followed local news closely when something important was happening, while $40 \%$ of them did so most of the time, or when something important was happening. Male respondents (83.2\%) were more likely than females $(43.4 \%)$ to follow local news closely only when something important was happening, while females $(56.3 \%)$ were more likely than males $(16.8 \%)$ to follow local news closely most of the time $\left(\mathrm{X}^{2}=195.61, \mathrm{df}=2, \mathrm{p}<0.000\right)$.

By country, Bahraini respondents $(81.7 \%)$ were more interested in following local news closely only when something important was happening, compared with $59 \%$ of KSA, $56 \%$ of Omani, $46.1 \%$ of Kuwaiti and $42.6 \%$ of UAE respondents. However, following local news most of the time, regardless of whether something important was happening, was reported by more UAE (57.4\%) and Kuwaiti (54\%) respondents than others (Omani 44.2\%, KSA 40.5\% and Bahraini 18.3\%) $\left(\mathrm{X}^{2}=107.66, \mathrm{df}=8, \mathrm{p}<0.000\right)$.

Interest in national news was also consistently high across different gender and country types. More than four fifths $(85.3 \%)$ of males reported following national news closely only when something important was happening, compared with $35.2 \%$ of females. However, $62.5 \%$ of females followed national news closely most of the time regardless of whether something important was happening, compared with only $15 \%$ of males $\left(X^{2}=302.8, d f=2, p<0.000\right)$. By country, Kuwaiti respondents $(92.2 \%)$ were most likely to follow national news closely only when something important was happening, compared with around half across all countries (Bahrain 55\%, Oman 52.3\%, KSA 50.4\% and UAE 47\%). Following news closely most of the time regardless of whether or not something important was happening was claimed by around half of respondents across all countries (53\% UAE, 50\% KSA, 48\% Oman, 41\% Bahrain). The lowest level of national news interest was found in Kuwait $(7.8 \%)\left(X^{2}=119.04, \mathrm{df}=8, \mathrm{p}<0.000\right)$.

Around half of all respondents $(52 \%)$ indicated that they followed international news closely regardless of what was happening (76\% Kuwait, 62.4\% Bahrain, 49\% UAE, 40\% KSA and Oman) $\left(\mathrm{X}^{2}=79.6\right.$, df=4, $\left.\mathrm{p}<0.000\right)$. More male respondents $(80.6 \%)$ than females $(30.2 \%)$ followed international news closely when something important was happening, while $70 \%$ of females were more likely to follow international news closely most of the time, regardless of whether or not something important was happening, compared with only $19.4 \%$ of males $\left(X^{2}=300.4, d f=1, p<0.000\right)$.

\subsection{Local News Sources Interest}

Evidence emerged here that GCC respondents used a variety of local news sources daily (RQ2). Social media sites (67\%), local FM radio (47\%) and online local newspapers (43\%) emerged as the local news sources reportedly most likely to be used daily, Table 1.

Table 1. Reported Following of Specific Local News Sources

\begin{tabular}{|c|c|c|c|c|c|}
\hline Tell me how often you use a... & Daily & $\begin{array}{c}\text { Few times a } \\
\text { week }\end{array}$ & $\begin{array}{c}\text { Few times a } \\
\text { month }\end{array}$ & $\begin{array}{l}\text { Less } \\
\text { often }\end{array}$ & Never \\
\hline - Person on a social media & 67.0 & 21.0 & 7.7 & 4.1 & 0.2 \\
\hline - Local radio FM & 46.9 & 26.7 & 14.4 & 10.2 & 1.5 \\
\hline - The website of local newspaper & 42.9 & 34.8 & 15.3 & 6.2 & 0.7 \\
\hline - Word of mouth (e.g., friends, family) & 35.0 & 32.4 & 22.5 & 7.6 & 2.5 \\
\hline - Local newspaper & 31.5 & 34.9 & 25.5 & 7.8 & 0.3 \\
\hline - Local TV news & 29.9 & 31.5 & 27.3 & 9.7 & 1.6 \\
\hline - The Internet via (e.g., Google) & 26.8 & 38.9 & 15.5 & 16.6 & 2.2 \\
\hline - The website of local radio FM & 18.5 & 18.8 & 29.7 & 18.7 & 14.3 \\
\hline - The website of local TV news & 10.6 & 26.4 & 31.2 & 16.1 & 15.8 \\
\hline
\end{tabular}


Interestingly, local newspapers and TV finished in almost equal fourth place on this measure and behind other platforms such as social media and local FM radio. These findings underline the emergence of the online media, especially social media such as Facebook and Twitter. Although respondents still have an appetite for consuming news from offline media, the popularity of these news platforms has clearly been superseded by the use of social media platforms.

There were significant gender differences regarding the reported frequencies with which different local news sources were used. Male respondents (95\%) were more likely than females (47\%) to report obtaining local news information from a person they followed on social media (U(1221)-92314.00; exact $\mathrm{p}<.000,2$-tailed). Male respondents (78\%) were also more likely than females (25\%) to get local information from FM radio (U(1221)-82235.00; exact p<.000, 2-tailed). The websites of local newspapers were more widely used as sources of local information by males $(84 \%)$ than by females (13\%) (U(1221)-47214.50; exact $\mathrm{p}<.000,2$-tailed).

By country, receiving local news daily from persons they followed on social media was the most popular platform for most respondents (UAE 90\%, Oman 68\%), but was relatively less prevalent among others (Kuwait 63\%, Bahrain 61\%, KSA $60 \%)\left(x^{2}(4, \mathrm{~N}=1221)=50.03, \mathrm{p}<.000\right)$. This finding also applied to word of mouth, which most of the respondents used for local news information (53\% UAE, 39\% Kuwait and Bahrain, 31\% Oman, 20\% KSA) $\left(x^{2}(4, \mathrm{~N}=1221)=54.22\right.$, $\mathrm{p}<.000)$.

UAE (47\%) and Kuwaiti respondents (45\%) were slightly more likely than other groups (Bahrain 36\%, KSA 27\%, Oman $13 \%)$ to read the print versions of local newspapers on a daily basis $\left(x^{2}(4, \mathrm{~N}=1221)=82.25, \mathrm{p}<.000\right)$. However, Kuwaiti (64\%) and KSA respondents (54\%) were more likely than the other groups (Oman 42\%, UAE 36\%, Bahrain $30 \%)$ to rely on the websites of local newspapers for local news $\left(x^{2}(4, \mathrm{~N}=1221)=49.79, \mathrm{p}<.000\right)$.

Local TV news was watched by more KSA (41\%) than Kuwaiti (34\%), Bahraini (32\%), UAE (27\%) and Omani respondents $(17 \%)\left(x^{2}(4, \mathrm{~N}=1221)=40.10, \mathrm{p}<.000\right)$. The websites of local TV news stations were not very popular among all the respondents (Bahrain 20\%, KSA 13\%, Kuwait 8\%, UAE 5\%, Oman 3.2\%) $\left(x^{2}(4, \mathrm{~N}=1221)=330.96\right.$, p <.000). Omani (67\%) and Kuwaiti respondents (55\%) were more likely than UAE (44\%), KSA (39\%) and Bahraini $(34 \%)$ respondents to follow local news on local FM radio $\left(x^{2}(4, \mathrm{~N}=1221)=53.17, \mathrm{p}<.000\right)$, while the websites of local FM radio stations were also not very popular among all respondents (Kuwait 29\%, Oman 25\%, Bahrain 19\%, KSA 15\%, UAE 6\%) $\left(x^{2}(4, \mathrm{~N}=1221)=183.73, \mathrm{p}<.000\right)$. UAE respondents (54\%) were more likely than the other groups (28\% Oman, $26 \%$ Kuwait, $25 \%$ KSA, $12 \%$ Bahrain) to use a search engine such as Google for local news $\left(x^{2}(4, \mathrm{~N}=1221)=26.32\right.$, $\mathrm{p}<.000)$. These findings confirmed those reported by Abdul Sadiq (2013), which indicated that most GCC students follow different radio programs online. It is clear that all the respondents' reliance on a greater diversity of local news sources may result from the fact that, as young people, they tend to have a greater understanding of technology, which offers them more avenues for gathering local information.

\subsection{Local News Preferences}

Respondents were asked to nominate their favorite local news sources (RQ3). Most respondents had different broad visions of local news sources favorites (67\%), compared with those who said that they 'don't have favorite' news (32.4\%) or 'don't follow' news $(0.3 \%)$. Significant differences were found at both gender and country levels. Most males $(95.5 \%)$ had favorite local news sources, compared with $47 \%$ of females $\left(X^{2}=320.28, \mathrm{df}=2, \mathrm{p}<0.000\right)$. By country, respondents had similar levels of local news preferences. Overall, more than three fifths of respondents had favorite local news sources (58\% KSA, 63\% Kuwait, 67\% UAE, 72\% in Bahrain and Oman) $\left(X^{2}=31.70\right.$, df=8, $\left.p<0.000\right)$.

With regard to preferred news sources, not surprisingly social media sites $(40.5 \%)$ such as Facebook and Twitter were the favorite sources of local news information across all nations, followed by local FM radio (23.5\%), local TV (16.3\%), and daily newspapers $(10.5 \%)$.

There were significant differences across gender and country profiles in respondents' preference for favorite local news sources or in perceptions of how well local news sources provided them with the information they needed. Interestingly, female respondents $(54 \%)$ were more likely than males $(22 \%)$ to report social media and daily newspapers (18\% vs. $0.8 \%$ respectively) as their favorite sources of local news and information. However, more male respondents (41\%) than females $(11 \%)$ reported local FM radio and local TV (36\% vs. $2 \%$ respectively) as their favorite sources of local news $\left(\mathrm{X}^{2}=548.37, \mathrm{df}=4, \mathrm{p}<0.000\right)$.

Over half of Kuwaiti respondents (57.4\%) preferred social media as a favorite source of local news information, compared with $45 \%$ in KSA, $42 \%$ in UAE, and $34 \%$ in Oman and Bahrain. However, local FM radio was named as a favorite news source more often in UAE (36\%) than in the other four countries surveyed (25\% KSA, 24\% Oman, $21 \%$ Bahrain, 9\% Kuwait). Around 1 in 5 of Bahraini (25\%) and Kuwaiti respondents (21\%) preferred local TV for local news, but only $18 \%$ of UAE, $10 \%$ of Omani and $9 \%$ of KSA respondents said as much $\left(\mathrm{X}^{2}=159.48, \mathrm{df}=16, \mathrm{p}<0.000\right)$. 


\subsection{Local News Sources Satisfaction}

In this study, around 4 in 9 (46\%) of all respondents said that local news sources provided 'all' of the information that matters to them, with an additional $35 \%$ indicating that these sources provided at least 'some' of the information they cared about. Male respondents (79\%) were more likely than females (22\%) to say that their local news sources provided 'all' of the information that matters to them $\left(X^{2}=392.77, \mathrm{df}=4, \mathrm{p}<0.000\right)$.

By country, Omani respondents (71\%) were more likely than the other nationalities (UAE 57\%, Bahrain 35\%, Kuwait and KSA both 31\%) to state that their local news sources delivered 'all' the information they were looking for. Around $45 \%$ of all respondents indicated that their local news delivered 'some' of the information they needed $\left(X^{2}=198.79\right.$, $\mathrm{df}=16, \mathrm{p}<0.000)$.

The flow of news and information today is different from that pertaining during the last decade (Anas, 2013). When the GCC respondents were asked whether they thought that seeking news about their local region was easier or harder compared to five years ago, around three quarters (75\%) of all respondents reported finding it 'easier' to keep up with local news and information today than it was five years ago. $17 \%$ of them found it 'harder' to keep up with local news. Only $6.2 \%$ of them said there was 'no real difference'. This low percentage may be due to those who lived in rural areas $(2.2 \%)$ where it is not easy to follow up-to-date news.

Male respondents $(94 \%)$ were more likely than females (61\%) to find it 'easier' to keep up with local news and information today. Only $28 \%$ of females and $1.6 \%$ of males believed it was 'harder' to keep up with the news. Females $(8 \%)$ were more likely than males $(4.3 \%)$ to say there was 'no real difference' between now and five years ago $\left(X^{2}=190.28, \mathrm{df}=3, \mathrm{p}<0.000\right)$.

While the majority of respondents reported that it was 'easier' today to keep up with local news (UAE 91\%, Bahrain $84 \%$, Oman $74 \%$, KSA $64 \%$, Kuwait $57 \%$ ), slightly less than one fifth of them (except Kuwaitis, at $42 \%$ ) said it was 'harder' today to keep up with local news. A few respondents $(6.2 \%)$ said there was 'no real difference' between today and five years ago $\left(\mathrm{X}^{2}=169.40, \mathrm{df}=12, \mathrm{p}<0.000\right)$. This result may be due, in part, to the rural respondents' reliance on traditional ways of gathering news and information; it may also be related to limited access to media platforms. These findings showed that those respondents find it 'easier' now to gain access to their local communities.

There was some evidence that respondents would like to receive their local newspapers online and that they are willing to pay a monthly subscription for such a service (24\%), although slightly more (27\%) said they already received a print version and online access free of charge. A few respondents said that their local newspapers were not available online $(17 \%)$ or that they were not willing to pay to receive them (15\%).

Male respondents (54\%) showed a much greater willingness than did females $(2.6 \%)$ to pay to subscribe to local news content. This may be because many female respondents (42\%) had access to print and online versions of their local newspapers, compared with only $5.3 \%$ of males $\left(\mathrm{X}^{2}=777.71, \mathrm{df}=5, \mathrm{p}<0.000\right)$. By country, UAE respondents $(51 \%)$ were more likely than respondents of any other country to have a paid subscription to a local newspaper (36\% Kuwait, $32 \%$ Oman, $12 \% \mathrm{KSA}, 7 \%$ Bahrain). Most Omani (39\%) and Bahraini respondents (31\%) said that they 'already get print version and online access' to their local newspapers, compared with $28 \%$ of KSA, $12 \%$ of UAE and $8 \%$ of Kuwaiti respondents $\left(X^{2}=351.11, \mathrm{df}=20, \mathrm{p}<0.000\right)$.

This result may stem, in part, from the fact that Omani, Bahraini and KSA respondents have more choices in gaining access to information and may need to depend more on a paid-for newspaper to obtain the material they seek. The next section explains this view in more depth.

\subsection{Interest in Local News Issues}

In this study, respondents were asked whether they followed nine different news and information issues (RQ4). Among all respondents, Table 2, it emerged that the most widely followed local issues were local government activities (83\%), local job openings (79.5\%), local services and help (78\%), local breaking news (77\%), local crime (76\%) and local restaurants, clubs or supermarkets $(71 \%)$, all of which were followed by a solid majority of three quarters or higher. A few respondents received news about their local schools and education (44\%), local events (41\%) and local political activities (40\%). 
Table 2. Claimed Interest in Specific Local News Issues

\begin{tabular}{lcc}
\hline & Frequency & Percent \\
\hline - Local government activities (e.g., local council meetings, local courts) & 1011 & 82.8 \\
- Local job openings & 971 & 79.5 \\
- Local services \& help (e.g., housing, food, healthcare) & 949 & 77.7 \\
- Local breaking news & 945 & 77.4 \\
- Local crime & 933 & 76.4 \\
- Local restaurants, clubs, or supermarkets & 863 & 70.7 \\
- Local schools \& education & 536 & 43.9 \\
- Local events (e.g., political activities) & 504 & 41.3 \\
- Local political activities, campaigns and elections & 485 & 39.7 \\
\hline
\end{tabular}

A further research question inquired into gender and country-by-country differences in news consumption patterns (RQ5). In all cases, the gender of respondents was related to local news issue interests, with males more likely than females to receive news of their local government activities ( $98 \%$ vs. $72 \%$ respectively; $X^{2}=143.36, d f=1, p<0.000$ ), local job openings $\left(99.6 \%\right.$ vs. $65.1 \%$ respectively; $\left.X^{2}=217.69, \mathrm{df}=1, \mathrm{p}<0.000\right)$, local social services and help $(98.4 \%$ vs. $63 \%$ respectively; $\left.\mathrm{X}^{2}=217.72, \mathrm{df}=1, \mathrm{p}<0.000\right)$, local breaking news $\left(98.6 \%\right.$ vs. $62 \%$ respectively; $\mathrm{X}^{2}=226.49, \mathrm{df}=1$, $\mathrm{p}<0.000)$, local crime ( $99 \%$ vs. $60 \%$ respectively; $\left.\mathrm{X}^{2}=253.56, \mathrm{df}=1, \mathrm{p}<0.000\right)$, local restaurants and clubs $(98 \%$ vs. $51 \%$ respectively; $\left.\mathrm{X}^{2}=326.65, \mathrm{df}=1, \mathrm{p}<0.000\right)$, local schools and education $\left(60 \%\right.$ vs. $32 \%$ respectively; $\mathrm{X}^{2}=95.69, \mathrm{df}=1$, $\mathrm{p}<0.000$ ), local events ( $49 \%$ vs. $37 \%$ respectively; $\left.\mathrm{X}^{2}=10.94, \mathrm{df}=1, \mathrm{p}=0.001\right)$, and local political activities ( $47 \%$ vs. $34 \%$ respectively; $\left.\mathrm{X}^{2}=20.32, \mathrm{df}=1, \mathrm{p}<0.000\right)$.

By country, receiving news on local government activities was more likely to be reported by Bahraini (96.7\%) and Kuwaiti respondents $(95.7 \%)$ than the others $\left(77.5 \%\right.$ Oman, $73 \%$ KSA, $71 \%$ UAE), $X^{2}=103.79, d f=4, p<0.000$. Local job openings were reported more by Bahraini respondents (93.1\%) than the others $(80.4 \%$ Oman, $78.8 \%$ KSA, $70.2 \%$ Kuwait, $62.7 \% \mathrm{UAE}$ ), $\mathrm{X}^{2}=78.20, \mathrm{df}=4, \mathrm{p}<0.000$. This result supported that of Ghannam (2012), which indicated that some Arab government officials are active contributors to social media platforms.

Obtaining news about local social services and help was reported more by Kuwaiti respondents $(91.5 \%)$ than the others (Bahrain and UAE both $81 \%, 74 \%$ Oman, $67.2 \% \mathrm{KSA})\left(\mathrm{X}^{2}=39.81\right.$, $\left.\mathrm{df}=4, \mathrm{p}<0.000\right)$. KSA respondents $(92 \%)$ were more likely than the others (87\% UAE, 85\% Kuwait, 72\% Bahrain, 65\% Oman) to receive news about local breaking information $\left(X^{2}=70.96, d f=4, p<0.000\right)$. Receiving news about local crime was reported more by Kuwaiti respondents $(97 \%)$ than the others (Bahrain and Oman both $84 \%$, KSA 64\%, UAE 59\%) $\left(\mathrm{X}^{2}=118.68, \mathrm{df}=4, \mathrm{p}<0.000\right)$. Obtaining local news about schools and education was cited by more Bahraini respondents $(80 \%)$ than the others (60\% Kuwait, 40\% KSA, 27\%, UAE, 9\% Oman) $\left(\mathrm{X}^{2}=357.92, \mathrm{df}=4, \mathrm{p}<0.000\right)$. More Bahraini and Kuwaiti respondents (both $91 \%$ ) said they obtained news about local political activities than did KSA (13\%), UAE (5\%) and Oman (4\%) respondents $\left(\mathrm{X}^{2}=847.19, \mathrm{df}=4, \mathrm{p}<0.000\right)$.

\subsection{Online Activities}

With regard to online activities (RQ6), the majority of respondents reported, Table 3, that they engaged in several online activities, such as posting news or information about their local community on Twitter (98\%), contributing to online discussions or topics about their local community (90\%), emailing local stories to others (78\%), commenting on a local news story they read online (67\%), customizing their homepage to include their favourite local information (66\%), contributing their own articles and opinions about their local community (63\%), and posting news about their community on Facebook (62\%). 
Table 3. Reported Online News-Related Activities

\begin{tabular}{lcc}
\hline & Frequency & Percent \\
\hline - Post news or info about your community on, e.g., Twitter & 1192 & 97.6 \\
- Contribute to an online discussion or topics about your local community & 1103 & 90.3 \\
- Email a link to a local news story/video to someone you know & 950 & 77.8 \\
- Comment on a local news story or local blog you read online & 820 & 67.2 \\
- Customise your homepage to include your favourite local info & 801 & 65.6 \\
- Contribute your own article/opinion/picture about your local community & 769 & 63.0 \\
- Post news or info about your community on, e.g., Facebook & 756 & 61.9
\end{tabular}

Respondents distinguished between the use of Twitter and Facebook. This result in particular confirmed several recent studies undertaken in the Arab world indicating that Twitter is a more popular platform in GCC countries than Facebook (Ghannam, 2012; Ghonim, 2012; Simsim, 2011; The Arab Social Media Report, 2012).

On most of the individual items measured here, male respondents were more likely to say they engaged in these activities than were females. Males were slightly more likely to post news about their local community on Twitter (99\% vs. $96 \%$ respectively; $\left.\mathrm{X}^{2}=12.12, \mathrm{df}=1, \mathrm{p}<0.000\right)$, contribute to an online discussion (99\% vs. $84 \%$ respectively; $\left.\mathrm{X}^{2}=72.56, \mathrm{df}=1, \mathrm{p}<0.000\right)$, email a local news story ( $96 \%$ vs. $64 \%$ respectively; $\left.\mathrm{X}^{2}=196.51, \mathrm{df}=1, \mathrm{p}<0.000\right)$, customize their homepage to include their favorite local news ( $96 \%$ vs. $44 \%$ respectively; $\left.X^{2}=352.66, d f=1, p<0.000\right)$, contribute their own articles and opinions (96\% vs. $39 \%$ respectively; $\left.X^{2}=413.10, \mathrm{df}=1, \mathrm{p}<0.000\right)$, post news about their community on Facebook ( $96 \%$ vs. $38 \%$ respectively; $\left.\mathrm{X}^{2}=420.30, \mathrm{df}=1, \mathrm{p}<0.000\right)$, and comment on a local news stories ( $74 \%$ vs. $62 \%$ respectively; $\left.\mathrm{X}^{2}=19.58, \mathrm{df}=1, \mathrm{p}<0.000\right)$.

By country, Bahrain respondents were the most likely to post news about their community on Twitter (99\% vs. $98 \%$ KSA, 97\% Oman, $95 \%$ both Kuwait and UAE; $\left.\mathrm{X}^{2}=11.56, \mathrm{df}=4, \mathrm{p}<0.000\right)$, contribute to an online discussion (99\% vs. 98\% Kuwait, 93\% UAE, 86\% Oman 78\% KSA; $\left.\mathrm{X}^{2}=90.70, \mathrm{df}=4, \mathrm{p}<0.000\right)$, email a news story link $(97 \%$ vs. $78 \%$ Kuwait, $73 \%$ both Oman and KSA 52\% UAE; $\mathrm{X}^{2}=161.30$, df=4, $\mathrm{p}<0.000$ ), comment on a local news story (99\% vs. $88 \%$ UAE, 75\% KSA, 67\% Kuwait 8\% Oman; $\mathrm{X}^{2}=648.02, \mathrm{df}=4, \mathrm{p}<0.000$ ), and customize their homepage (82\% vs. $76 \%$ Kuwait, $68 \%$ KSA, 65\% UAE, 40\% Oman; $\left.\mathrm{X}^{2}=131.15, \mathrm{df}=4, \mathrm{p}<0.000\right)$. Kuwaiti respondents $(79 \%)$ were more likely than the others $\left(71 \% \mathrm{KSA}, 65 \%\right.$ Bahrain, 56\% UAE, 45\% Oman) to post local news via Facebook $\left(\mathrm{X}^{2}=65.36\right.$, $\mathrm{df}=4, \mathrm{p}<0.000)$. KSA (95\%) and Kuwaiti (94\%) respondents were more likely than the others $(84 \%$ UAE, 36\% Bahrain, 34 Oman) to contribute their own articles and opinion pieces about their local community $\left(\mathrm{X}^{2}=422.91, \mathrm{df}=4, \mathrm{p}<0.000\right)$.

\section{Conclusion}

This study investigated how university students obtain local news and information in different GCC regions. Media and communication students were asked to state their opinions regarding their local community news. Most respondents who indicated that they enjoyed keeping up with the news a 'lot' (52\%) in general (RQ1) indicated similar rates of following local and national news closely only when something important was happening. A slim majority of respondents across all countries reported following international news as closely (52\%). Interest in local news was highest among Bahraini respondents, followed by KSA and Omani respondents, while interest in national news was highest among Kuwaiti respondents (RQ2). Milinay (2013) found that Saudi students tend to use the Internet to search for different news, and they pay more attention to international news than local or national news.

A further result indicated that respondents preferred different news sources for local news (RQ3). Social media, especially Twitter, were part of their everyday experiences, with respondents reporting them as their favorite sources for local news daily, which suggests that social media have provided them with 'all' or most of the information they seek. This is similar to the study reported by Arab Social Media (2012), which found that the number of Arab people in the GCC region using social media as sources of information continues to grow rapidly.

With regard to particular local news issues (RQ4), this study found that, in general, respondents were interested in some news issues and had different levels of interest in others. Bahraini and Kuwaiti respondents were more likely to be interested in local government activities, local schools and education, local political activities, and local services and help than others. KSA and Kuwaiti respondents were more likely to follow local breaking news than others. Similarly, TV and the Internet were found to be used regularly by young adults for national and international news (Sopher, 2010). Young Arab students were found to consume different news issues depending on where they are located, and they continue to express an awareness of and an interest in a variety of social and political issues (Elareshi, 2013).

This is an indication that respondents were able to make distinctions between different news issues and it confirms 
research conducted by Western and Arab media organizations. A survey conducted by the Pew Research Center in the US found that $77 \%$ of those aged 18 to 29 years reported being interested in following 'local news politics and political issues', as (cited in Greenberg \& Weber, 2008). It was also found that 36\% of young Americans aged 18 to 25 years report an interest in keeping up with national affairs (Kohut, Parker, Keeter, Doherty, \& Dimock, 2007).

Different news consumption patterns and preferences between genders and across nations were found (RQ5). For example, respondents who lived in UAE and Oman relied more on social media sites for local news and information than did others. Similar results cited elsewhere found that Arab GCC people rely more on social media for their local news and current events (28\%) and for news on various issues (Miliany, 2013; The Arab Social Media Report, 2014). Omani and Kuwaiti respondents were more likely to obtain local news and information via local FM radio than others. Respondents who lived in Kuwait and KSA relied more on the websites of local newspapers for local news than others and were more likely to receive local news via their local TV.

The current study found that respondents were very active regarding their local communities' news on online sites, as most of them have posted local news via Twitter, contributed to online discussions, emailed a local news story link to others, and commented on a local news story online (RQ6). Bahraini respondents were more likely to engage in these activities than were others. This is a clear indication that respondents are finding a space online to express their opinions and enjoy freedoms (Ghannam, 2012). However, expressing opinions online remains risky in most of the Arab world (Freedom House, 2013).

Furthermore, the majority of respondents concurred that, these days, it is 'easier' to keep up with local news and information than it was years ago. This may be due to the spread of new technologies that have made the flow of information much quicker now. However, respondents are the least willing to pay for local news content through a paid subscription to a local newspaper. UAE respondents were the most likely to worry about what might happen should their local newspaper no longer exist.

\section{Acknowledgments}

The authors would like to express their gratitude to the Pew Research Center for allowing the use of the questionnaire in this survey.

\section{References}

Abdel Rahman, H. (1998). Uses and gratifications of satellite TV in Egypt. Transnational Broadcasting Studies, (1).

AbdulSadiq, A. (2013). The motives of university students' in Bahraini universities use of online radio: A field study. Strategic Vision, 114-149.

Aday, S., Farrell, H., Lynch, M., Sides, J., \& Freelon, D. (2012). New media and conflict after the Arab spring. United States Institute of Peace. Washington, DC.

Ajami, F. (2012). The Arab spring at one: A year of living dangerously. Foreign Affairs, 91, 56-65.

Al-Jaber, K., \& Gunter, B. (2013). News developments and changes to news consumption patterns in the Arab world. In B. Gunter \& R. Dickinson (Eds.), News media in the Arab world: A study of 10 Arab and Muslim countries (pp. 135-152). New York: Bloomsbury.

Al-Shaqsi, O. S. (2000). The influence of satellite and terrestrial television viewing on young adults in Oman: Uses, gratifications and cultivation. (Doctoral dissertation, University of Wales. Cardiff).

Anas, O. (2013). Changing profile of media in the Arab states. Global Media Journal, 2(1-2), 28-46.

Ayish, M. (2001). American-style journalism and Arab world television: An exploratory study of news selection at six Arab world satellite television channels. Transnational Broadcasting Studies, (6).

Ayyad, K. (2011). Internet usage vs. traditional media among university's students in the United Arab Emirates. Journal of Arab and Muslim Media Research, 4(1), 41-61.

Barakat, R. (2011). New media in the Arab world: A tool for redesigning geopolitical realities. Lebanese American University, Lebanon.

Boyd, D. (1999). Broadcasting in the Arab world: A survey of the electronic media in the Middle East. Iowa: Iowa State University Press.

Boyd, D., \& Shatzer, M. (1993). Television viewing habits of Saudi Arabian young adults. Gazette, 51, $137-148$.

Colombo, S. (2012). The GCC countries and the Arab spring: Between outreach, patronage and repression. Paper prepared for the Istituto Affari Internazionali. Roma, Italy. 
Correa, T., Hinsley, A. W., \& de Zuniga, H. G. (2010). Who interacts on the web? The intersection of users' personality and social media use. Computers in Human Behavior, 26, 247-253. http://dx.doi.org/10.1016/j.chb.2009.09.003

Dennis, E., Martin, J., \& Wood, R. (2013). Media use in the Middle East: An eight-nation survey. Retrieved December 10, 2013, from http://menamediasurvey.northwestern.edu/

Dennis, E., Martin, J., \& Wood, R. (2014). Entertainment media use in the Middle East: A six-nation survey. Retrieved March 23, 2014, from http://mideastmedia.org/

Dutta-Bergman, M. J. (2004). Complementarity in Consumption of News Types across Traditional and New Media. Journal of Broadcasting and Electronic Media, 48(1), 41-60. http://dx.doi.org/10.1207/s1550687jobem4801_3

Elamanza, A., Tahat, K., \& Sweis, R. (2013). Media in the Middle East: Perception of news credibility in Jordan government-owned media versus private media. European Journal of Social Sciences, 40(1), 143-153.

Elareshi, M. (2013). News consumption in Libya: A study of university student. Newcastle: Cambridge Scholars Publishing.

Elareshi, M., \& Al-Jaber, K. (2014). The new media as alternative medium in the GCC region: the growing influence of social networks. Paper prepared for the Social Media and the Changing Context of Politics in the Gulf Workshop. Cambridge: Gulf Research Meeting.

Elareshi, M., \& Gunter, B. (2010). News consumption among young Libyan adults: Are new satellite TV news services displacing local TV news. Arab Media \& Society, (12).

Elareshi, M., \& Gunter, B. (2012). Patterns of news media consumption among young people in Libya. Journal of African Media Studies, 4(2), 173-191.

Ellison, N. B., Steinfield, C., \& Lampe, C. (2007). The benefits of Facebook "friends": Social capital and college students' use of online social network sites. Journal of Computer-Mediated Communication, 12, 1143-1168. http://dx.doi.org/10.1111/j.1083-6101.2007.00367.x

Eva, B. (2012). Reconsidering the robustness of authoritarianism in the Middle East: Lessons from the Arab Spring. Comparative Politics, 44(2), 127-149. http://dx.doi.org/http://dx.doi.org/10.5129/001041512798838021

Freedom House. (2013). Freedom in the World. Retrieved April 14, 2014, from http://freedomhouse.org/report/freedom-world/freedom-world-2013\#.U0uSdfm-1cY

Gant, C., \& Dimmick, J. (2000). Making local news: A holistic analysis of sources, selection criteria, and topics. Joumalism \& Mass Communication, 77(3), 628-938. http://dx.doi.org/10.1177/107769900007700311

Ghannam, J. (2012). Digital media in the Arab world one year after the revolutions. Center for International Media Assistance.

Ghareeb, E. (2000). New media and the information revolution in the Arab world: An assessment. The Middle East Journal, 54(3), 395-418.

Ghonim, W. (2012). Revolution 2.0: The power of the people is greater than the people in power: A Memoir. New York: Houghton Mifflin Harcount.

Greenberg, E. H., \& Weber, K. (2008). Generation we: How millennial youth are taking over America and changing our world forever. US: Pachatusan.

Gunter, B. (2010). Television versus the Internet: Will TV prosper or perish as the world moves online? Oxford: Chandos Publishing.

Heikkinen, K., \& Reese, S. (1986). Newspaper readers and a new information medium. Communication Research, 13(1), 19-36. http://dx.doi.org/ 10.1177/009365028601300103

Howard, P. N., Duffy, A., Freelon, D., Hussain, M., Mari, W., \& Mazaid, M. (2011). Opening closed regimes: What was the role of social media during the Arab Spring? Seattle: PIPTI. Retrieved April 23, 2014, from http://pitpi.org/index.php/2011/09/11/opening-closed-regimes-what-was-the-role-of-social-media-during-the-arabspring/

Huang, E. (2009). The causes of youths' low news consumption and strategies for making youths happy news consumers. Convergence, 15(1), 105-122.

Karam, I. (2007). Arab satellite broadcasting, identity and Arab youth. (Doctoral dissertation, City University London. $\mathrm{UK})$. 
Kohut, A., Parker, K., Keeter, S., Doherty, C., \& Dimock, M. (2007). A portrait of “generation next”: How young people view their lives, futures and politics.

Levy, M., \& Windahl, S. (1984). Audience activity and gratifications: A conceptual clarification and exploration. Communication Research, 11, 51-78. http://dx.doi.org/ 10.1177/009365084011001003

Lin, K. Y., \& Lu, H. P. (2011). Why people use social networking sites: An empirical study integrating network externalities and motivation theory. Computers in Human Behavior, 27, 1152-1161. http://dx.doi.org/10.1016/j.chb.2010.12.009

Marghalani, K., Palmgreen, P., \& Boyd, D. (1998). The utilization of direct satellite broadcasting (DBS) in Saudi Arabia. Journal of Broadcasting \& Electronic Media, 42(3), 297-314. http://dx.doi.org/ 10.1080/08838159809364451

Metzger, M. J., Flanagin, A. J., \& Zwarun, L. (2003). College student Web use, perceptions of information credibility, and verification behavior. Computer and Education, 41, 271-290. http://dx.doi.org/10.1016/S0360-1315(03)00049-6

Miladi, N. (2006). Satellite TV news and the Arab diaspora in Britain: Comparing Al-Jazeera, the BBC and CNN. Journal of Ethnic \& Migration Studies, 32(6), 947-960. http://dx.doi.org/ 10.1080/13691830600761552

Miladi, N. (2011). New media and the Arab revolution: Citizen reporters and social activism. Journal of Arab \& Muslim Media Research, 4(2/3), 3-5.

Miliany, K. (2013). The impact of the internet on Saudi students' use of television. University of Leicester.

Pempek, T., Yermolayeva, Y., \& Calvert, S. (2009). College students' social networking experiences on Facebook. Journal of Applied Developmental Psychology, 30, 227-238. http://dx.doi.org/10.1016/j.appdev.2008.12.010

Pew Research Center for the People and the Press. (2002). Public's news habits little changed by September 11. Retrieved May 23, 2014, from http://bit.ly/cqyy15

Rugh, W. (2004). Arab mass media: Newspapers, radio, and television in Arab politics. London: Praeger.

Ryan, Y. (2011). How Tunisia's revolution began. Al-Jazeera English. Retrieved November 21, 2013, from http://english.aljazeera.net/

Schwarz, R. (1994). Uncle Sam online: Government information on the Internet. Communication Education, 43, 151-158. http://dx.doi.org/10.1080/03634529409378972

Simsim, M. T. (2011). Internet usage and user preferences in Saudi Arabia. Journal of King Saud University Engineering Sciences, 101-107.

Sopher, C. K. (2010). Younger thinking: An evaluation of young America and the future of news media and civic life. Retrieved June 05, 2014, from http://youngerthinking.com/upload/ResearchPaper-reduced.pdf

The Arab Social Media Report. (2012). Social media in the Arab world: Influencing societal and cultural change? Retrieved June 24, 2014, from www.dsg.ae/en/imagees/ASMR4finaltopost.pdf

The Arab Social Media Report. (2014). The Arab World Online 2014. Retrieved May 20, 2014, from http://www.mbrsg.ae/getattachment/ff70c2c5-0fce-405d-b23f-93c198d4ca44/The-Arab-World-Online-2014-Trend s-in-Internet-and.aspx

The Arabic network for Human Rights. (2004). The Internet in the Arab world a new space of repression: Libya the Internet in a conflict zone. Retrieved May 23, 2014, from http://anhri.net/en/reports /net2004/libya.shtml

Yuan, Y., \& Kosicki, G. M. (2003). Citizen use of Internet and traditional news media sources: What's new about new media? Paper presented at the annual meeting of the International Communication Association, Marriott Hotel. San Diego, CA.

Zerba, A. (2004). Growing up with parents who read and watch the news: What is the effect on college students. Paper presented at the Association of Education for Journalism and Mass Communication Annual Conference. Toronto.

\section{(cc) $\mathrm{BY}$}

This work is licensed under a Creative Commons Attribution 3.0 License. 